\title{
A church with character and its social capital for projects amongst the poor
}

\begin{abstract}
Author:
Hendrik J.C. Pieterse ${ }^{1}$

Affiliation:

${ }^{1}$ Department of Practical

Theology, University of

Pretoria, South Africa

Correspondence to:

Hennie Pieterse

Email:

pietehjc@absamail.co.za

Postal address:

262 Marais Street, Brooklyn

0181, South Africa

\section{Dates:}

Received: 16 Mar. 2011

Accepted: 23 May 2011

Published: 04 Nov. 2011

How to cite this article: Pieterse, H.J.C., 2011, 'A church with character and its social capital for projects amongst the poor', HTS Teologiese Studies/ Theological Studies 67(3), Art. \#1046, 8 pages. http:// dx.doi.org/10.4102/hts. v67i3.1046
\end{abstract}

C 2011. The Authors. Licensee: AOSIS OpenJournals. This work is licensed under the Creative Commons Attribution License.
In this article I present a theoretical framework for my argument that specific congregations which are renewed to address the current culture and context, according to the vision presented by Professor T.F.J. Dreyer, are competent to generate projects directed to the poor and humble as social capital. The problem addressed in the article, also phrased as the research question, is: what is the nature and diversity of care in the form of projects as social capital amongst the poor in renewed congregations as it emerges from the sermons on Matthew 25:31-46? The goal of the grounded theory analysis of sermons on this text in a research cycle of selective coding, collected from renewed congregations, will be the identification of projects, types of projects, and their properties. I discuss the idea of local theologies as a motivation of contextual religious action by the congregation in projects amongst the poor, provide a description of poverty in South Africa; show the role of religious faith communities in addressing poverty, followed by conceptualisation of social capital in projects of congregations, and lastly I give a description of two examples of projects thus far discovered in analysed sermons.

\section{Introduction}

It is a privilege for me to honour professor Theuns Dreyer, a longstanding colleague in the teaching and study of homiletics, with a contribution regarding this discipline. I want to focus on his recent work on the nature of the local congregation of mainline churches in a changed culture and in a postmodern context (cf. Dreyer 1998, 2003, 2005, 2006 and 2009), as a connection with my own research on the role of the local congregation in using social capital of its members in reaching out to the poor in our context. The work of professor Dreyer in this regard connects critically with Heitink's view of a re-oriented or renewed church in the 21st century (cf. Heitink 2009). The theological ideas of Heitink and Dreyer are relevant for all Reformed churches also the Nederduitsch Hervormde Kerk, the Nederduitse Gereformeerde Kerk and the Uniting Reformed Church. My argument is that such a renewed congregation is able to provide social capital for reaching out to the poor in South Africa.

My research of preaching on poverty started in 2001, proceeded in 2009 and is now taken further in a six-year project (cf. Pieterse 2004 and 2009). In this project I am doing a grounded theory research of sermons on Matthew 25:31-46 by preachers of the Dutch Reformed Church (Nederduitse Gereformeerde Kerk) and the Uniting Reformed Church. The research proceeds in three cycles. The first cycle of an open coding analysis of twelve sermons has now been completed (cf. Pieterse 2010). A clear pattern has emerged from the sermons of what preachers in this innerworld of twelve sermons are saying and doing in their sermons on this biblical text: preachers are appealing to the listeners of the sermon by employing their faith participation with Jesus, in order to appeal to them to choose for identifying with the poor and humble, and then appealing to them for caring for the poor and humble in the present context of the congregations in South Africa. There is a theoretical dimension of consequence in the process of appealing in the sermons, namely that on the grounds of the listeners' faith participation with Jesus the consequence is that they identify with the poor as Jesus did, with the consequence that they (as a congregation) should care for them. There is also a theoretical dimension of time in the sermons, namely that reference is made to Jesus' ministry (past), it is actualised for today (present) and the consequence of not identifying and caring for the poor is that they could miss the Kingdom of God (future).

From this open coding analytical model that is constructed as a result of the open coding analysis in the first cycle of research, three hypotheses developed: the discovery that Jesus identifies with the poor and humble (Hypothesis 1), the appeal on the congregation to identify with the poor and humble (Hypothesis 2), and the appeal on the congregation to care for the poor and humble (Hypothesis 3).

The second cycle of research will now focus on the third hypothesis (the care of the congregation for the poor). Sermons will be collected in 2011 by means of selective coding from preachers on 
the same preaching text from congregations with character (in Dreyer's vision) where projects amongst the poor are undertaken. For the selection of the congregations and their preachers I am looking for congregations that approach the 'dream' of Dreyer of a renewed church fit for contemporary culture - a congregation with an inner circle of committed church members with a movement from the inside to the outside and back to the inside (Dreyer 2009:431). Such a church has eight factors that identify it. I am focusing on one of them, namely diakonia, where there is a unity of word and deed in the outreach to people outside the church (Dreyer 2009:429) - in my focus to the poor and humble. The basic sensitising concept that I am using to open the data in the selective coding of sermons in the second cycle will be projects by members of the congregation amongst the poor. Properties of the concept of projects must now be found. This will enable me in a third cycle of research to construct a grounded theory (from the bottom up) of preaching Matthew 25:31-46 on poverty in our context.

The problem addressed in this research project is in general the situation of the poor and humble in South Africa and the role the church can play in its preaching to address this problem. The specific problem in this second cycle of selective coding has to do with the question: what is the nature and diversity of care in the form of projects as social capital amongst the poor in the aforementioned churches as it emerges from the sermons on Matthew 25:31-46? This is also the research question. From the results of the first cycle of research it is clear that the diversity of properties of the projects run by members of the congregations amongst the poor will now be the focus. Therefore the goal of the grounded theory analysis of sermons on this text, collected from preachers preaching in the transformed congregations geared at the current culture and contexts, will be the identification of projects and their properties as social capital from congregations in their outreach to the poor. This article, as a first step in the research of the second cycle in the project, explores the theoretical aspects that come into play when the problem and the goal of the research are addressed.

In this article I will therefore firstly discuss the idea of local theologies as a motivation of contextual religious action by the congregation in order to reach out in projects to the poor, provide a description of poverty in South Africa, the role of religious faith communities in addressing poverty, followed by conceptualisation of social capital in projects of congregations as local theologies, and lastly a description of two examples of projects thus far discovered in the analysed sermons.

\section{Local theologies in context as motivation for projects amongst the poor}

As part of a theoretical framework for my argument in this article, namely that specific congregations that have transformed to address current culture contextually with the
Gospel, and in discipleship, reach out inter alia in projects to the poor, I discuss the idea of local theologies as motivation for church members to voluntary participate in projects amongst the poor and humble in their own contexts. Local theologies can have nuances in the theological tradition of a church denomination as a result of a congregation's history, context and in the diversity in spirituality. Practical theologian Robert Schreiter formulated the concept of constructing local theologies as a contextual enterprise (Schreiter 1985). He works with a hermeneutical interpretation of the culture of a specific congregation that has an influence on the theological understanding of such a congregation as a result of the interaction with their theological tradition and the current culture in their context. Schreiter as well as Browning (1991) work with the cultural anthropological approach of Clifford Geertz (1973). The gist of this approach is that the social reality of a community is seen as a cultural web. In this cultural web beliefs, the confessional creeds, history of a congregation, attitudes, morals, customs, practices and the environment form an intertwined whole that is a cultural web: 'I take culture to be those webs, and the analysis of it to be ... an interpretative one in search of meaning' (Geertz 1973:5). Browning put this hermeneutical approach in the realm of practical philosophy in the manner that Gadamer (1982) developed his hermeneutical theory (Browning 1991:37-41). I am comfortable in this hermeneutical framework and have worked with Gadamer's hermeneutic in all my homiletic studies.

To construct a local theology the researcher has to view the members of the congregation as participants in the research. The experience near of the participants, their views and opinions, their theological understanding of their context and their congregation are very important in the process of constructing a local theology by the action of the experience distant of the researcher. The views and understanding of the participants and the more objective understanding and description of that congregation by the researcher, are supplementary. These observations form a thick description. In a contextual view, taking the diversity in postmodern culture into consideration, nearly every congregation in its own history, theological history, confessional creeds and belief, spiritual diversity, and unique environment has a local theology in context. Examples of thick descriptions as local theologies of three different congregations are given by Browning in his case studies of Wiltshire Methodist Church, the Church of the Covenant and the Apostolic Church of God (Browning 1991:15-33). Once such a congregation is researched in this way, self-understanding is possible and therefore transformation can happen.

In my grounded theory research on preaching and poverty the preachers are participants in the research. I analyse their sermons to find out what they are saying and doing in the sermons and to get information in the sermons of the projects of the congregation amongst the needy that the preachers want their listeners to participate in as an action of diakonia with their voluntary work as social capital. From 
the information in the sermons and the different projects the congregations are running in their contexts, a local theology can be spotted. The participating churches are Reformed churches, but the local theology within their Biblical based theology has to do with the context of the congregation. It is exactly the specific theological understanding of the functioning of the congregation of a specific congregation that motivates the nature of the projects of that congregation amongst the poor.

\section{Poverty in South Africa}

An important factor to understand the motivation for members of the congregation in their voluntary service as social capital in projects amongst the poor is a profile of poverty in South Africa. In 2000 about $50 \%$ of the population of South Africa lived beneath the bread or poverty line and was regarded as poor. The poverty line is a cut-off point, above which people can maintain a minimum standard of living, but below this it is not possible (cf. Pieterse 2004:30). Since then there was an increase in poverty (Burger, Louw \& Van der Watt 2010:66). Although the government has involved more people in social grants, nearly 14 million in 2010, the gap between rich and poor increases - the rich elite gets richer and the poor masses get poorer. Characteristics of the poor are diseases caused by bad circumstances, lack of proper housing, lack of good education, joblessness and helplessness and vulnerability (cf. Pieterse 2004:31). They are excluded from the well-being of their countrymen, and experience injustices against them (cf. Burger, Louw \& Van der Watt 2010).

Wepener and Cilliers (2010) listed more factors than just the lack of income in their description of poverty; they call it a diverse definition in the light of their understanding of social capital. Against the feeling of a sense of belonging and the formation of trust and identity, poverty could be described as exclusion. The poor are denied their identity as human beings and as members of society. Against the command of civic skills the poor lack useful civic skills:

Poverty could indeed be described or defined as: a state of affairs where the absence of material resources, lack of space to enable the formation of trust and identity, as well as the loss of civic skills and collaborative opportunities to further real transformation, impact negatively on one another in a seemingly unstoppable and escalating spiral.

(Wepener \& Cilliers 2010:420)

Poverty is spread all over the country; from the analysed sermons in the first cycle of open coding analysis it is clear that the contexts addressed in the sermons do not differ much between Uniting Reformed Church (mainly Black congregations) and Dutch Reformed Church (mainly White congregations). I visited several provinces in South Africa to collect the sermons and had conversations with the preachers on their contexts. It seems that poverty is spread all over the country and the poor are on every one's doorstep. Of course the poverty situation differs in different South African towns, cities and rural areas as do the contexts of the congregations of the two churches where I am conducting my research on preaching and poverty.

\section{The role of religious faith communities in addressing poverty}

In determining the social capital that a congregation can contribute in its specific context and its specific kind of projects amongst the poor, it is necessary to understand the role of faith communities in addressing poverty. Faith based communities have unique characteristics when we oversee the field of organisations that are active in addressing poverty in South Africa. Van der Merwe and Swart (2010) make use of the typology by Sider and Unruh of faith based communities. They distinguish five categories of organisations, such as faith-permeated, faith-centered, faithaffiliated, faith-background and faith-secular organisations. The typical Christian congregation with a weekly worship service, managed by a church council, and the variety of ministries for the committed inner circle of church members with a movement from the inside to the outside and back to the inside, can be typified as a faith-permeated organisation:

Faith-permeated organizations are organizations in which the connection with religious faith is clearly evident on all levels ... In these types of organizations it is believed that the faith dimension is essential for the effectiveness of the programme and participation in religious exercises is often a prerequisite.

(Van der Merwe \& Swart 2010:79)

Every faith community has its own view of how to be involved in society and in the social needs of individuals and communities. The outreach to the poor can take different forms. It can involve individuals or small groups of people who reach out informally, or there can be organised programmes aimed at a whole community (Van der Merwe \& Swart 2010:84). This, of course, pertained to local theologies that inform and motivate the congregation's outreach to the poor. In my analysis of sermons on Matthew 25:31-46 in the second cycle of selective coding I am working with the concept of projects by members of the congregation amongst the poor in organised programmes.

The outreach programmes of faith communities are an important part of the non-profit sector of social welfare and development amongst the poor and comprise almost $16 \%$ of the total of organisations active in this field. Furthermore, they have immense sources of people available to reach out in projects amongst the poor. According to the South African Population Census of 2001, 84\% of South Africans claim to be affiliated to a religious group, of which the vast majority is Christians. Faith communities enjoy high levels of trust amongst the population according to a 2000 Human Research Council report on public attitudes, of which $74 \%$ of the respondents indicated that they trust churches (Burger, Louw \& Van der Watt 2010:68).

The role of projects amongst the poor by congregations is energised and inspired in worship services with the sermon at the heart of the service in the two Reformed 
denominations that are part of my research. Wuthnow emphasises that congregations make their members aware of the need, motivate and inspired them to join the projects of outreach to the needy with their social capital (cf. Wuthnow 2004:94). This idea is confirmed in my report on the first cycle of analysis of what preachers are saying and doing in sermons on Matthew 25:31-46 which has revealed that the central concept in the sermons is appealing on the listeners to identify with the poor and humble and care for them (cf. Pieterse 2010). This idea is also confirmed by the research of Wepener and Cilliers (2010) on ritual and the generation of social capital in contexts of poverty. Ritual in the worship service generates a sense of belonging and relations of trust, helps with the development of civil skills and service in the development of material infrastructure and resources, and it opens up opportunities to further transformation (Wepener \& Cilliers 2010:422-426).

Christian congregations play a major role in generating social capital by means of the voluntary service of their members in projects that address poverty in South Africa. The worship service with a sermon on Sundays is a central place of awareness, motivation and inspiration of church members to participate in the unique kind of projects of specific congregations informed by their contexts and contextual local theologies.

\section{Conceptualisation of social capital in congregations}

Projects by church members amongst the poor and needy as social capital is in the focus of my selective coding cycle that may emerge in the analysis of sermons on Matthew 25:31-46. As part of the theoretical framework of the second cycle of research it is necessary to conceptualise social capital as it is generated in the worship service with its preaching dimension and in the voluntary actions of church members in projects by the congregation.

The concept of social capital was introduced in the 1970s. One of the pioneers of research on social capital is Robert D. Putnam (2001); his findings on religion are interesting. Putnam's research has shown that religious people are very active in volunteering work - they are social capitalists. Involvement in religion is a strong predictor of voluntary work inside and outside the church. Putnam distinguishes two types of social capital, namely bonding social capital which tends to reinforce exclusive identities, and bridging social capital which tends to bring people together across diverse and social divisions (De Roest \& Noordegraaf 2009:216). A third type of social capital, called linking social capital has been distinguished by John Field which implies reaching out to people outside the community (De Roest \& Noordegraaf 2009:216). Three concepts in social capital come to the fore: bonding, bridging and linking.

Further refinement of the concept of social capital followed and a distinction was made between religious and spiritual capital. Religious capital is the practical contribution to the community made by faith groups. Spiritual capital energises religious capital by providing theological identity and a worshipping tradition (De Roest \& Noordegraaf 2009:217). It is important to note that the theological tradition, which we can call a local theology in a specific congregation, and the worship tradition play an important role in the motivation and inspiration of the social capital of that congregation. Making use of the concepts of religious capital and spiritual capital the Church of England in a report in 2006 states that churches can make a particular contribution to urban life, especially in the poor neighbourhoods (De Roest \& Noordegraaf 2009:217). In the research by De Roest and Noordegraaf, they found that there is a relationship between social capital, religiosity and volunteering in the Netherlands. Regular churchgoers do more voluntary work than other members of the church and non-church members. This is true inside the church and in outreach to people outside the church. They also found that churches are favourable settings for all kinds of social engagements, and that religious-moral motivation works through networks of friendships between church members. Face-to-face relations in these networks translate the religious-moral motivation into social action (De Roest \& Noordegraaf 2009:220).

Wepener and Cilliers (2010) follow Ammerman's train of thought on the description of social capital. Ammerman has participated in research in the United States of twentythree congregations in terms of the impact of social change and transformation on congregations, but also the impact of congregations on social change and transformation in society. She came to the insight that congregations are generators of social capital. Wepener and Cilliers (2010) summarise Ammerman's conclusion:

... that congregations offer certain markers for identification
and a sense of belonging. Relationships of trust are formed here,
and these relationships in turn facilitate communication and the
co-ordination of activities in society and contribute towards the
well-being of participants. Individuals, as well as the broader
society, benefit from this. In addition to this basic inherent social
capital that congregations possess, they are also places where the
voiceless can articulate their concerns. (Wepener \& Cilliers 2010:418)

Congregations possess infrastructure as well as material and human resources that are critical components of the social capital of congregations (Wepener \& Cilliers 2010:419). This fact is the reason why my research on preaching and poverty is conducted amongst preachers of mainline churches in the Reformed family, namely the Dutch Reformed Church (Nederduitse Gereformeerde Kerk) and the Uniting Reformed Church. The congregations in these churches have the infrastructure and the resources to be able to reach out to the poor in their contexts.

It is necessary that we interpret and describe social capital and its function in the South African context; there is a variety of descriptions and interpretations of this concept. We must be aware of the danger of an insignificant intellectual discussion of social capital in our context. Wepener and Cilliers (2010) 
have made a good contribution in this respect. They decided to attach an added dimension to the 'linking' aspect of the three, namely bonding, bridging and linking:

With 'linking' the possibility for ideological discussion and conflictual dialogue is held open. In other words, the dominant economic model and status quo are not protected in any way ... Matters like equity and justice, power, and the redistribution of wealth and assets come into play. The one-way movement from those who 'generate' social capital to those who 'receive' it is transformed into an equitable partnership where holders of power (political, economic and social) are confronted and invited into a truly reciprocal transformation of society, This is not a 'neutral, stance on, or discussion about social capital, but a process of linking in which ideological presuppositions are not only questioned, but also shattered and transformed.

(Wepener \& Cilliers 2010:419)

Therefore, they add a fourth dimension to the three dimensions of social capital that is generally accepted, namely that congregations are spaces within which a new ethos is born and nurtured:

an ethos that confronts structures and constellations of power, and works in collaboration with other relevant agencies towards a real transformation of society in terms of equity and justice.

(Wepener \& Cilliers 2010:419)

This line of thought regarding the participation between the church for the poor and the church of the poor on an equal footing in the exchange of social capital to each other is also promoted by Pieterse (2004:11-118).

To summarise we can say that the concept of social capital has the dimensions of bonding, bridging and linking. In the South African context we add a deeper dimension to linking in the sense that it is a space for confrontational dialogue challenging ideologies and power in order to transform our society in the context of poverty to a situation of equity and justice. Furthermore, congregations are the spaces where the generation and exchange of social capital can take place. Wepener and Cilliers (2010:422-426) make a list of the nature of social capital which ritual in the worship service can generate, namely a sense of belonging and relations of trust, help with the development of civil skills, inspiration of worshippers to offer their lives as a living sacrifice and service in the development of material infrastructure and resources, and the opening up of opportunities to further transformation.

Preaching as part of the worship service has a specific role in the generation of social capital in the worship service. It has the space where the congregation can be addressed on the need for care of the poor. In sermons the congregation can be made aware of the situation and the needs of the poor and humble in the vicinity of the congregation; they can be motivated and inspired to participate in the projects of the congregation where they can practice their care for the poor as social capital; and the projects can be specified and the service groups for each project can be named. Therefore it is necessary in my analysis of sermons on Matthew 25:31-46 to identify the projects of care for the needy in the sermons and attach properties to them. This will help me in developing a bottom-up theory from the practice of preaching this text on poverty.

\section{Projects of care for the poor in two diverse congregations}

In the second cycle of selective coding I am making use of sensitising concepts that build on those used in the first cycle in order to open up the data in the sermons (cf. Pieterse 2010), but now I am adding the concept 'projects by members of the congregations amongst the poor' as social capital. From the open coding analysis of twelve sermons in the first cycle the concept of 'appealing' emerged from the data. In their sermons on Matthew 25:31-46 a few examples of projects run by the congregation as care emerged from the sermons. In the second cycle, I am looking for projects in the data and I am trying to identify their nature and diversity. It will be interesting to see what the preachers are saying and doing in these congregations. I am still busy with selecting renewed congregations in the new culture and context mentioned earlier as transformed, collecting sermons and analyse them. As illustration of the theoretical argument of this article I now present significant segments from two sermons of preachers of the Dutch Reformed Church in two renewed congregations that differ in context and sources.

\section{Preacher M}

\section{Gender: male; age group: middle; education: high;} province: Kwazulu-Natal

He is the only pastor in a congregation of between 500-600 members. The members are mostly middle class people. The context of the congregation in Kwazulu-Natal, and the poor in their midst, the specific history and theological tradition as well as the spirituality of the people, form a local theological nuance in the Dutch Reformed Church. The Afrikaansspeaking church members are for more than a century in the minority in this province amongst English-speaking South Africans, Indian South Africans and Zulus.

The theme of preacher M's sermon from Matthew 25:31-46 is that our goal is to care for others. The love of God for us should be practiced in caring for others. In the analysis of his sermon significant segments emerged in the light of the research question, namely what is the nature and diversity of care in the form of projects amongst the poor in the transformed congregations as it emerges from the sermons on Matthew 25:31-46? Regarding segment A the preacher refers to the nature of the first Christian congregation in Acts 4:32-33. In segment A:

'As believers we need to be one in heart and mind. When we do that we will have an impact and make a difference in the world around us. These first Christians remembered what they were in the past, chained in sin, and the grace and love they received from God. They realized how great the unselfish love of the Lord is. This inspires them to be unselfish and generous to people next to them. In this way they look after each other in their material needs. Important are their deeds of sacrifice. They took their own money and food en gave it to people around them ... The 
reason for this attitude is because they were one in heart and mind. They were personally involved with each other... They were sensitive to the need of others and that empowered them to practice the love of God to others.'

(Preacher M, Sermon from Matthew 25:31-46, excerpt from segment A, n.d.)

Here the following occurs:

- The preacher calls on the believers to be one in heart and mind.

- The preacher reminds them that if they do that they will have an impact on the world around them.

- The preacher says that the first Christians knew their sin and the grace and love of God.

- The preacher says that this knowledge inspires them to be unselfish and generous in caring for each other.

- The preacher reminds of the sacrifice of their money and food to other people.

- The preacher says they were personally involved with each other and sensitive to the needs of others.

In this segment preacher M motivates his congregation to open up their hearts and minds to the people in need around them because of God's love and grace for them. This knowledge inspires them to practice the love of God to people in need. In segment $B$ :

'Come and practice your Christian faith by getting involved with one of the following projects where our congregation is active: the distribution of food packets and the gospel to the jobless people sitting at the BP petrol station next to the church; the giving of groceries on a monthly basis to the elderly in Tuinsig centre for the aged in Durban; help with the toiletry, clothes, linen and birthday presents for orphans in the Greytown orphanage for all races where our congregation joins hands with other Dutch Reformed congregations; get involved with the need at Haven of Rest Centre for AIDS orphans, elderly people picked up in the streets, as well as marginalized youth in Tongaat; the St. Luke's Centre for retarded people in Stanger.'

(Preacher M, Sermon from Matthew 25:31-46, excerpt from segment B, n.d.)

Here the following occurs:

- The preacher invites the listeners to get involved in the congregation's projects.

- The preacher names the projects one by one: distribution of food packets with the bringing of the gospel to the jobless; groceries for the elderly in the home for the aged; clothes and toiletry for orphans in an orphanage; the support for Haven of Rest; and the centre for retarded people in Stanger.

It is striking that the preacher invites the congregation to participate in the projects, and that the projects by way of information are named one by one.

\section{Preacher $\mathbf{N}$}

\section{Gender: male; age group: young; education: high; province: Gauteng}

He is one of a team of four fulltime pastors in this up market congregation of professional and higher middle class people. It is a large congregation of 2400 members with good financial and human resources. The congregation is situated in a different context in Gauteng and is significantly different from Preacher M's context. The Afrikaans-speaking community is since the establishment of this city in the majority amongst the English speaking community in this city, and the White community is on par in number with the Black community. The congregation is renewed and geared towards the new culture and context, and has its own spiritual and theological history. It forms in this city a nuance amongst the Dutch Reformed congregations and can therefore be viewed as a congregation with an own local theology. It functions with service groups for each ministry and the members run the projects managed by a pastor. The theme of Preacher N's sermon from Matthew 25:31-46 can be described as: 'the time bomb is ticking ... the gospel and poverty'. In segment A:

'We are called by the soft voice of God, the One who wants to call us to a better future. It is the God who uses the gospel to move people so that they can live free and light... God moves in front of us into the future. His call comes to us in different forms. One of these calls we find in Matthew 25 ... it is a call full of hope! ... We must look at the movement which is already taking place. We can see with excitement how people on many places already answer God's call.'

(Preacher N, Sermon from Matthew 25:31-46, excerpt from segment A, n.d.)

Here the following occurs:

- The preacher says that God is calling the listeners to a better future (in the context of poverty).

- The preacher announces that God uses the gospel to move people in order to live free and in lightness.

- The preacher says that God is moving in front of us into the future.

- The preacher states that God calls us in this text, and it is a call full of hope.

- The preacher calls on the listeners to look at the movement that is already taking place.

- The preacher says we can be excited by many people's reaction on God's call.

In segment B:

'We are involved in direct alleviation of poverty in Danville, Sunnyside and Pretoria North. We want to invite you to participate in our projects in a way that will enrich your life (shows the projects on screen): food for Paul Jungnickel Home for Adults with Disabilities; support for House Piek for the elderly; support for Harmonie Oord for the poorer elderly; support in food et cetera for the poor community of Claremont and/or Danville; weekly classes for adult literacy - those who never learn to read and write; Tabita sewing classes for women in order to be able to make clothes; support for the Centre of Contextual Ministry where poorer pastors are taught for ministry; support for the salaries of pastors of Mabeskraal and Dinokana Kgote congregations; support for the Jacaranda Children's Home; and support for Sun Sparrows nursery school. May you experience that God moves you to be a bridge-builder to the promised land.

(Preacher N, Sermon from Matthew 25:31-46, excerpt from segment $B$, n.d.)

Here the following occurs:

- The preacher says that the congregation is involved in the alleviation of poverty in areas of the city. 
- The preacher invites the listeners to participate in the projects that will enrich their lives.

- The preachers shows the projects on the PowerPoint screen (see Segment B).

- The preacher expresses his wish that the listeners may experience God's movement in their lives.

\section{Two types of projects}

We can distinguish two types of projects in these two congregations: projects of charity and projects of development, self-help and transformation which is a first initial step in finding properties of projects - in this case two very distinct types of projects. I reported the analysis of only two sermons as an illustration of projects with distinct properties directed to the poor in renewed congregations. With the analysis of more sermons I can concentrate on the identification of more properties of projects.

\section{Congregation of preacher $\mathbf{M}$}

Projects of charity: In the congregation of preacher M most the projects are charity outreaches with different destinations and goals which is also an indication of their properties.

Project of development, self-help and transformation: The Haven of Rest is a unique kind of project. It caters for marginalised people, whom the Christians usually find sleeping on the streets. The piece of land where it is situated belonged to the Hullett sugar cane industry, became a possession of a bank from which pastor Ronnie Naidoo of the Apostolic Faith Mission bought it. There are houses with house mothers for AIDS orphans, a house for the homeless elderly where young people are also catered for from time to time, and a clinic. The inhabitants of the Haven have to cook, clean and do all the work at the establishment; they are helped to help themselves. Different churches support the project, but the congregation of preacher $\mathrm{M}$ is the only Dutch Reformed Church-congregation that supports this project.

\section{Congregation of preacher $\mathbf{N}$}

Projects of charity: The first four of the list of projects give support in food and clothes to ease the plight of the needy. These projects are also directed at different destinations and goals which is also an indication of properties of these projects. In a next article, focusing on more sermon analyses, I will address the diversity of properties of projects to the poor and needy.

Projects of development, self-help and transformation: The last six projects in the list include projects that help the needy to develop with the goal being to help them-selves or to work with children, pastors and church members, with a view on growth and development.

\section{Enriching of the central concept}

In the open coding analysis of the first cycle the central concept of the way the preachers address the listeners is appealing. A new initial central concept from the two sermons is now added: inviting. It will be interesting to see if this approach in transformed congregations emerges in the further analysis of sermons.

\section{Conclusion}

In this article I present a theoretical framework for my argument that specific congregations that are renewed to address the current culture and context, according to the vision presented by Professor T.J.F. Dreyer, are competent to generate projects directed to the poor as social capital.

For such a theoretical framework the following conceptual aspects discussed in the article are important:

- local theologies in context serve as motivation for church members to participate in these projects

- an academic description of poverty in South Africa to become aware of the problem in the vicinities of congregations

- in determining the contribution of social capital of volunteering church members in projects directed to the poor, we must understand the role of religious faith communities in addressing poverty (to do that we must determine the place of our congregations in a typology, namely faith-permeated organisations)

- to underpin the argument of the article a conceptualisation of social capital is necessary.

I close the article with an illustration of effective projects to the poor in two of these renewed but diverse congregations as they emerged from the analysis of two sermons on Matthew 25:31-46.

It is clear that congregations that approach the 'dream' of Dreyer of a renewed church fit for contemporary culture - a congregation with an inner circle of committed church members with a movement from the inside to the outside and back to the inside (Dreyer 2009:431) - have the competence and motivation to reach outside the inner circle to the poor in other contexts with effective projects as social capital to make a difference in South Africa.

\section{Acknowledgements Competing interests}

This article is part of a project with financial support by the National Research Foundation.

\section{References}

Browning, D.S., 1991, A fundamental practical theology, Fortress Press, Minneapolis, $\mathrm{MN}$.

Burger, R., Louw, M. \& Van der Watt, C., 2010, 'The challenge of poverty and social exclusion post-apartheid South Africa', in I. Swart, H. Rocher, S. Green \& J. Erasmus (eds.), Religion and social development in post-apartheid South Africa, pp. 61-73, SUN Press, Stellenbosch.

De Roest, H.P. \& Noordegraaf, H., 2009, "'We learned it at our mothers' knees": Perspectives of churchgoing volunteers on their voluntary service', Reformed World 59(3), 213-226.

Dreyer, T.F.J., 1998, 'Spiritualiteit, identiteit en die etos van die Nederduitsch Hervormde Kerk', HTS Teologiese Studies/Theological Studies 54(1\&2), 289-314. 
Dreyer, T.F.J., 2003, 'Statistiekevertel 'n storie - 'n Visievir die Hervormde Kerk op pad na 2010', HTS Teologiese Studies/Theological Studies 59(4), 1045-1062.

Dreyer, T.F.J., 2005, 'Kenotieseprediking - die katalisatorvirliturgieseverdieping in die huidigekonteks', HTS Teologiese Studies/Theological Studies 61(93), 93-108.

Dreyer, T.F.J., 2006, 'Die akkommodering en bestuur van diversiteit in gemeenteverband', HTS Teologiese Studies/Theological Studies 62(4), $1337-1368$.

Dreyer, T.F.J., 2009, "n Kerk met karakter: Die perspektief van Gerben Heitink', HTS Teologiese Studies/Theological Studies 65(1), 427-431.

Gadamer, H-G., 1982, Truth and method, Crossroad, New York.

Geertz, C., 1973, The interpretation of culture, Basic Books, New York, NY.

Heitink, G., 2009, Eenkerk met karakter: Tijdvoorheroriëntatie, Kok, Kampen.

Pieterse, H.J.C., 2004, Preaching in a context of poverty, University of South Africa, Pretoria.
Pieterse, H.J.C., 2009, 'Predikingoor die konikryk van God: 'n Uitdaging in ' $n$ nuwekonteks van armoede', HTS Teologiese Studies/Theological Studies 65(1), 14-20.

Pieterse, H.J.C., 2010, 'An open coding analytical model of sermons on Matthew 25:31-46 as sermon text', submitted to ActaTheologica.

Putnam, R.D., 2001, Bowling alone: The collapse and revival of American community, Simon \& Schuster, New York, NY.

Schreiter, R., 1985, Constructing local theologies, Orbis Books, Maryknoll, NY.

Van der Merwe, W. \& Swart, I., 2010, 'Towards conceptualizing faith-based organizations in the context of social welfare and development in South Africa', in I. Swart, H. Rocher, S. Green \& J. Erasmus (eds.), Religion and social development in post-apartheid South Africa, pp. 75-89, Sun Press, Stellenbosch.

Wepener, C. \& Cilliers, J., 2010, 'Ritual and the generation of social capital in contexts of poverty', in I. Swart, H. Rocher, S. Green \& J. Erasmus (eds.), Religion and social development in post-apartheid South Africa, pp. 417-430, SUN Press, Stellenbosch.

Wuthnow, R., 2004, Saving America: Faith based services and the future of civil society, Princeton University Press, Princeton, NJ. 